\title{
The Influence of Principal Managerial Competencies and Interpersonal Communication on Teachers Performance in Samanhudi Tanjung Pura Private Senior High School
}

\author{
Chandra \\ Sekolah Maitreyawira \\ Deli Serdang, Indonesia \\ chandrakusuma_minz@yahoo.com
}

\author{
Mananda Situmorang, \\ Mahyudin Situmeang, \\ Universitas Pembinaan Masyarakat Indonesia \\ Education Administration \\ Medan, Indonesia
}

\begin{abstract}
A principal must have five basic competencies: personality competence, managerial competence, entrepreneurial competence, supervisory competence and social competence. In managerial competence, a principal is expected to be able to plan, organize, mobilize and evaluate the school properly and responsibly so that he can improve teacher performance. Good interpersonal communication skill is expected to create a conducive work climate so that it can play a role in improving teacher performance. This study aims to explain the influence of principals' managerial competencies on teacher performance in Samanhudi Tanjung Pura Private Senior High School, the influence of interpersonal communication on teacher performance in Samanhudi Tanjung Pura Private Senior High School, and explain the influence of principal managerial competencies and interpersonal communication with teacher performance at Samanhudi Tanjung Pura Private Senior High School. This study uses a quantitative approach. Data collection uses a questionnaire consisting of variable principal managerial competence, interpersonal communication and techer performance. The number of respondents is 30 people. While to test the hypothesis with path analysis techniques (path analysis) by using multiple linear regression analysis techniques (multiple regression). The results showed that principal managerial competence, interpersonal communication and teacher performance in Samanhudi Tanjung Pura Private Senior High School was in the moderate category, then by comparing the $t_{\text {count }}$ $>t_{\text {table }}(2.976>2.052)$ there is an influence between the principal managerial competencies on teachers performance, while seeing the comparison of $t_{\text {count }}<t_{\text {table }}(1.969<2.052)$ means there is no influence between interpersonal communication on teachers performance, and collectively the $t_{\text {count }}<t_{\text {table }}$ shows that there is no joint effect between principal managerial competence and interpersonal communication on teachers performance in Samanhudi Tanjung Pura Private Senior High School. Thus, managerial competence has a significant influence on improving teacher performance so that a principal must always improve his managerial competencies in order to improve teacher performance without forgetting other factors that also affect teacher performance.
\end{abstract}

Keywords -Principal managerial competency, interpersonal communication, teacher performance.

\section{INTRODUCTION}

Teachers play a very important role because teacher is the spearhead of education. Therefore, the success of education in Indonesia is depend on teacher performance. Qualified and professional teachers are believed to be able to produce qualified, dignified and charactered human resources. But it is very unfortunate that to get qualified and professional teachers at this time is very rare while teachers determine the success of a country's education.

Lately there are symptoms of a tendency to weaken teacher performance. ${ }^{[1]}$ Sumadi (2012) stated that teachers carry out their duties only modestly without any material preparation or teaching methods used. The teacher doesn't master the material strongly so that learning becomes monotonous and ends quickly. It will affect the learning outcomes.

Therefore, nowadays we need a principal who can accommodate the aspirations and the needs of the teachers in order to improve their performance so that the quality and professionalism of the teachers could be achieved

Principals are expected to be able to motivate and implement a managerial system in order to create a working climate and good communication between individuals to work together, hand in hand to improve performance to achieve the goals set by school. ${ }^{[2]}$ Abdul Wahab and Umiarso (2010), defining leadership is an activity influencing others so that people want to work together (collaborating and elaborating their potential) to achieve the goals set. To make these people work well together in a good working climate, good communication between individuals is needed.

To make the managerial system that has been implemented by the principal can be implemented properly, it requires directed, structured and measurable communication so that what is conveyed both from the principal, fellow teachers and education staff can be properly understood by the listeners so that the purpose can be delivered optimally.

The objective of this study is to investigate the influence of principal managerial competencies and interpersonal communication on teachers performance in Samanhudi Private Senior High School. 
In this study, researchers formulated the following hypothesis (1) $\mathrm{H}_{0}$ : Principal managerial competencies and interpersonal communication have no influence on teachers performance at Samanhudi Tanjung Pura Private Senior High School, (2) Ha: Principal managerial competencies and interpersonal communication have influence on teachers at Samanhudi Tanjung Pura Private Senior High School.

\section{THEORY FRAMEWORK}

\section{A. Principal Managerial Competency}

Budi Suhardiman (2012) cited Spencer and Spencer stated that a competency is an underlying effective and/or superior performance in a job or situation. Five characteristics of competency : (1) motives (2) traits (3) self concept (4) knowledge and (5) skill. ${ }^{[3]}$

According to the Minister of National Education Regulation Number 13/2007 a School/Madrasah Principal must have five competencies including managerial competencies.

Referring to Robert Bacal's thoughts in Koswara and Halimah (2012) management on teacher performance is always closely related to the principal's task to always carry out continuous communication, through partnership with all teachers in his school. ${ }^{[4]}$

In accordance with the description of James A.F. Stoner in Wahijosumidjo (2010) principal as a manager is essentially a planner, organizer, manager and a controller.

\section{B. Interpersonal Communication}

According to De Vito as quoted by Hanani (2017) said that interpersonal communication is a message sent by someone to another person with the effect of his message directly. Furthermore, Hanani also quoted Mulyana saying that interpersonal communication is communication between people face to face that allows each participant to capture the reactions of others directly. ${ }^{[5]}$

Rakhmat in Ngalimun (2017) believes that interpersonal communication is influenced by interpersonal perception, self concept, interpersonal attraction and interpersonal relationships. ${ }^{[6]}$

\section{Teacher Performance}

According to Muhammad Ilyas Ismail (2013) performance is the achievement achieved by someone in carrying out their duties or work during a certain period in accordance with the standards and criteria set for the job. ${ }^{[7]}$ From the statement we know that performance tends to be identified with work performance. A teacher can be said to have a good performance if in the learning process teacher can increase students interest in learning and students can reach the Minimum Passing Grade that has been set. This also in line with the opinion of Muljono Damopoli (2012) which states that achievement does not mean how many championships are obtained by teachers, but how successful the teacher impact in learning process.
While according to Muhammad Yaumi (2014) teacher performance is the level of ability in designing and implementing learning, communication skills, classroom management and interpersonal relationships possessed by teachers to bring students towards better. ${ }^{[8]}$

Analyzing teacher performance indicators related to learning, systematically teacher performance can be known through the abilitiy and skills in planning learning programs, implementing learning programs and evaluating learning programs.

\section{METHODOLOGY}

This study is to determine whether there is influence of principal managerial competency and interpersonal communication on teacher performance at Samanhudi Private Senior High School.

\section{A. Research Approach}

The approach used in this study is a quantitative approach to the type of correlational research to determine the relationship between two or several variables.

\section{B. Research Place}

This research was conducted at Samanhudi Private Senior High School at Jalan Pemuda Number 55 Tanjung Pura, Langkat, North Sumatra, Indonesia.

\section{Description of times}

- Preliminary observations before the study January March 2018

- Collection of literacy and materials April - June 2018

- Research proposal seminar July 2018

- Pretest and sample determination August 2018

- Research time July - September 2018

- Time for writing reports October - November 2018

\section{Population and sample}

Samanhudi Private Senior High School has 30 teachers. The sample for this study was all of the 30 teachers in Samanhudi Private Senior High School consist of 10 men and 20 women.

\section{E. Data Analyzing}

The instrument in this study was in the form of a questionnaire given to respondents to be answered in accordance with their personal characteristics and experiences so that data on principal managerial competence, interpersonal communication and teacher performance could be obtained.

- Validity and Reliability of Test Instrument

The validity and reliability test was done to make sure this research instrument is valid and reliable with SPSS Statistics 20 analyzing data program. Validity test has been tested by comparing the correlation value with $r$ table are 
searched at 0.05 significance with 2 -sided test and the amount of data $(\mathrm{n})=30$, so $\mathrm{r}$ table is 0.361 according to the attachment in Table $\mathrm{r}$ (Pearson Correlation) ${ }^{[9]}$ Sugiyono (2016). Then with the Cronbach's Alpha reliability test method, data are stated to have reliability if the alpha value $>$ value in table $r$ (for $n=30 ;$ 2-tailed test; $r$ table $=0.361$ ). From the instrument reliability calculation results alpha $r$ value is positive and greater than $r$ table (0.361), so it can be said that the variable instrument has a level of reliability and can be used as a measuring tool.

- Descriptive Data Analysis

In Arikunto (2017) stated that quantitative data collected in correlational research are processed with statistical formulas that have been provided, both manually and using computer services. ${ }^{[10]}$ Data analysis conducted on the formulation of problems that are descriptive is to use the mean and standard deviation on the grounds that the researchers have previously determined that the data provided by repondents in response to the questionnaire were normally distributed.

- Regression Prerequisite Test

Research that uses regression analysis necessitates the fulfillment of a number of basic assumptions before further testing is carried out

- Normality Test

Normality test is a test used to test the distribution of data in the normal category or not. The normality test in this study uses the SPSS Statistics 20 software assistance using the Kolmogorov Smirnov Test through Descriptive Explore Analyze. ${ }^{[10]}$ In Sudarmanto (2010) is written that normality is met if data or points are collected around a straight line. Population data can be assumed to be normally distributed if the p-value $>\alpha$ with a real level $\alpha=0.05$ with the conditions: if $p$-value $\geq 0.05$, the data are normally distributed.

- Linearity Test

Linearity test basically aims to find out whether or not the linear relationship of each variable. Linearity testing criteria with the help of the SPSS Statistics 20 program if Fcount $\geq 0.05$ the data is linear.

- Multicollinearity Test

The multicollinearity test was conducted with the aim of finding out whether there were any deviations from the classical assumptions, namely the existence of a linear relationship between the independent variables. If the VIF value $<10$, then the multicollinearity does not occur and if VIF > 10 then multicollinearity occurs.

\section{- Hypothesis Test}

Analysis in the hypothesis test is based on data obtained from respondents through a questionnaire that has been distributed in this study. We use regression analysis to determine the shape of the relationship between variables. Then the relationship between the two variables can be tested using the Pearson Product Moment formula. Simultaneous linear regression test is a statistical test of regression which together affect $\mathrm{Y}$ and use the $\mathrm{F}$ test in its test. Finally we use joint hypothesis tesing to determine the effect of the independent variables together on the dependent variables. The hypothesis used is (1) H0: There is influence of Principal Managerial Competencies and Interpersonal Communication on Teacher Performances, (2) Ha: There is no influence of Principal Managerial Competencies and Interpersonal Communication on Teacher Performances. Based on probability: $\mathrm{HO}$ is accepted if significant $>0.05$. H0 is rejected if significant $<0.05$

\section{RESEARCH RESULT}

Based on the results of data calculations, Principal's managerial competence, interpersonal communication and teacher performance at Samanhudi Private Senior High School are in the moderate category.

From the Kolomogorov- Smirnov Test results stating that the Asymp value. Sig. (2-tailed) $>0.05$ so that the three varialbes can be said to be normally distributed.

\begin{tabular}{|c|c|}
\hline Variable & Asymp. Sig \\
\hline 1. Principal Managerial Competency & 0,608 \\
\hline 2. Interpersonal Communication & 0,260 \\
\hline 3. Teacher Performance & 0,665 \\
\hline
\end{tabular}

The significance value of all variable in linearity test are greater than 0.05 so it can be concluded that the variable regression line is linear so that it can be used to predict the magnitude of the teacher performance variable.

TABLE 2. LINEARITY TEST RESULTS

\begin{tabular}{|c|c|c|c|c|}
\hline Variable & Significancy & Alpha & Cond. & Conclusion \\
\hline 1. $\mathrm{Y} * \mathrm{X}_{1}$ & 0,084 & 0,05 & $\mathrm{~S}>\mathrm{A}$ & Linear \\
\hline 2. $\mathrm{Y} * \mathrm{X}_{2}$ & 0,682 & 0,05 & $\mathrm{~S}>\mathrm{A}$ & Linear \\
\hline
\end{tabular}

A good regression model should not occur correlation between independent variables so that these variables are orthogonal. To detect whether there is a multicollinearity problem can see the tolerance value and Variance Inflation Factor (VIF). Regression models in this study do not have multicollinearity problems between independent variables since VIF $(1.000)<10$ and are appropriate to be used as a regression model.

TABLE 3. MULTICOLLINEARITY TEST RESULTS

\begin{tabular}{|cc|r|r|}
\hline \multirow{2}{*}{} & \multicolumn{2}{|c|}{ Collinearity Statistics } \\
\cline { 2 - 4 } & Model & Tolerance & \multicolumn{1}{c|}{ VIF } \\
\hline 1 & (Constant) & & \\
& X1 & 1.000 & 1.000 \\
& X2 & 1.000 & 1.000 \\
\hline
\end{tabular}


Multiple regression equation of the teacher performance variable on the Principal Managerial Competence and interpersonal communication variables are:

$$
Y=74,762+0,024 X_{1}+0,009 X_{2}
$$

Based on the results SPSS Statistics 20, a value of 0.025 is obtained. The correlation number of 0.025 shows that simultaneously the principal managerial competency and interpersonal communicaiton on teacher performance has a positive linear relationship.

Based on the hypothesis testing $\mathrm{X}_{1}$ and $\mathrm{X}_{2}$ against $\mathrm{Y}$ that have been done, the probability value (Asymp. Sig. $)=0.976>$ $0.05 ; \mathrm{t}_{\text {count }}=0.030<\mathrm{t}_{\text {table }}=2.052$ for variable $\mathrm{X}_{1}$ and the probablity value (Asymp. Sig.) $=0.092>0.05 ; \mathrm{t}_{\text {count }}=0.010<$ $\mathrm{t}_{\text {table }}=2.052$ for variable $\mathrm{X}_{2}$. The following are the results of hypothesis testing through SPSS Statistics 20.

\section{TABLE 4. HYPOTHESIS TEST RESULTS $X_{1}$ AND $X_{2}$ AGAINST $Y$}

\begin{tabular}{|c|c|c|c|c|c|}
\hline \multirow[b]{2}{*}{ Model } & \multicolumn{2}{|c|}{$\begin{array}{l}\text { Unstandardize } \\
\text { d Coefficients }\end{array}$} & \multirow{2}{*}{$\begin{array}{c}\text { Standardize } \\
\mathrm{d} \\
\text { Coefficients } \\
\\
\text { Beta }\end{array}$} & \multirow[b]{2}{*}{$\mathrm{t}$} & \multirow[b]{2}{*}{ Sig. } \\
\hline & B & $\begin{array}{l}\text { Std. } \\
\text { Error }\end{array}$ & & & \\
\hline 1 (Constant) & $\begin{array}{r}76.6 \\
49\end{array}$ & $\begin{array}{r}26.63 \\
9\end{array}$ & & 2.877 & .008 \\
\hline $\mathrm{X} 1$ & .006 & .182 & .006 & .030 & .976 \\
\hline $\mathrm{X} 2$ & .003 & .299 & .002 & .010 & .992 \\
\hline
\end{tabular}

The hypothesis test shows that there is acceptance of $\mathrm{H} 0$ and rejection of $\mathrm{H} 1$. This acceptance of $\mathrm{H} 0$ means that there is no significant joint effect on the Principal Managerial Competence and Interpersonal Communication on teacher performance at Samanhudi Tanjung Pura Private Senior High School

\section{CONCLUSION \& SUGGESTIONS}

\section{A. Conclusion}

Principal managerial competence, interpersonal communication and teacher performance at Samanhudi Tanjung Pura Private Senior High School are in the medium category. The principal has been able to make school plans, but in organizing and moving the school there are still obstacles in his first year as principal.

There is an influence on the principal managerial competence on teacher performance. Interpersonal communication has a positive impact on teacher performance, but the influence of interpersonal communication is so small that it hardly gives an influence on teacher performance. At last there is no joint influence between principal managerial competence and interpersonal communication on teacher performance in Samanhudi Tanjung Pura Private Senior High School

\section{B. Suggestions}

1) Interpersonal communication at Samanhudi Tanjung Pura Private Senior High School needs to be improved and directed to further enhance the enthusiasm of working enthusiastically so that they can support each other in creating creativity and completing all programs which are well planned and on time. Basically, teachers already have good interpersonal perception.

2) Principals need to organize far more directed, measured and structured so that the implementation will create efficiency and effectiveness.

3) Principal needs to instill a self-concept in accordance with the vision and mission that the school wants to achieve in teachers.

4) Teachers already have good planning skills. But in terms of the implementation of learning needs to be improved so that it can bring positive results for students at school.

5) In communicationg when carrying our duties as teacher, the teacher must have a clear self-concept, be able to distinguish between professional and private matters.

6) The results of this study can add to the treasury and enrich empirical information in terms of principal managerial competence, interperssonal communication and teacher performance including the dimensions examined in it so that it can be used as comparative data or references by changing or adding other variables so that they can also improve this research.

\section{REFERENCES}

[1] Sumadi. Penyakit Guru Masa Kini.Yogyakarta : Candra. 2012.

[2] Wahab HS, Abd \& Umiarso. Kepemimpinan Pendidikan dan Kecerdasan Spiritual. Jogjakarta : Arruzz Media. 2010.

[3] Suhardiman, Budi. Studi Pengembangan Kepala Sekolah. Jakarta : Rineka Cipta. 2012.

[4] Koswara, Deni dan Halimah. Kebiasaan Kepala Sekolah Efektif. Cet. II. Bandung : Pribumi Mekar. 2012

[5] Mulyasa. H.E. Manajemen dan Kepemimpinan Kepala Sekolah, Cet. II.Jakarta : PT Bumi Aksara. 2012.

[6] Ngalimun. Ilmu Komunikasi Sebuah Pengantar Praktis. Yogyakarta : Pustaka Baru Press. 2017.

[7] Ismail, Muhammad Ilyas. 2013. Guru Sebuah Identitas. Samata Gowa : Alauddin University Press. 2013.

[8] Yaumi, Muhammad. Model Perbaikan Kinerja Guru dalam Pembelajaran. Gowa: Alauddin University Press. 2014.

[9] Sugiyono. Statistika Untuk Penelitian. Bandung : Alfabeta. 2016.

[10] Arikunto, Suharsimi. Prosedur Penelitian : Suatu Pendekatan Praktek. Jakarta : RinekaCipta. 2017 